\title{
Sensory analysis of specialty coffee from different environmental conditions in the region of Matas de Minas, Minas Gerais, Brazil ${ }^{1}$
}

\author{
Alice de Souza Silveira ${ }^{2 *}$, Aracy Camilla Tardin Pinheiro ${ }^{2}$, Williams Pinto Marques Ferreira ${ }^{3}$, \\ Laércio Junio da Silva ${ }^{2}$, José Luis dos Santos Rufino ${ }^{4}$, Ney Sussumu Sakiyama ${ }^{2}$
}

$10.1590 / 0034-737 X 201663040002$

\begin{abstract}
Specialty coffees can be differentiated in various ways, including the environmental conditions in which they are produced and the sensory composition of the drink. This study aimed to evaluate the effect of altitude, slope exposure and fruit color on the sensory attributes of cafes of the region of Matas de Minas. Sampling points were georeferenced in four altitude ranges $(<700 \mathrm{~m} ; 700 \leq x \geq 825 \mathrm{~m}, 825<\mathrm{x}<950 \mathrm{~m}$ and $\geq 950 \mathrm{~m}$ ) of the coffee crop; two fruit colors of var. Catuaí (yellow and red); and two slope exposures (North-facing and South-facing). Coffee fruit at the cherry stage were processed and submitted to sensory analysis. The sensory attributes evaluated were overall perception, clean cup, balance, aftertaste, sweetness, acidity, body and flavor, which made up the final score. The scores were examined by ANOVA and means were compared by the Tukey test $(\mathrm{p} \leq 0.05)$. From the sensory standpoint, coffee fruits of both colors are similar, as well as the coffees from both slope exposures when these factors were analyzed separately. However, at higher altitudes, Yellow Catuaí produces coffees with better sensory quality. Similarly, coffees from North-facing slopes, at higher altitudes produce better quality cup. The altitude is the main factor that interferes with coffee quality in the area. All factors together contribute to the final quality of the beverage produced in the region of Matas de Minas.
\end{abstract}

Keywords: Coffea arabica; quality cup; altitude; slope exposure; fruit color.

\section{RESUMO}

\section{Análise sensorial dos cafés especiais da região das Matas de Minas cultivados em diferentes condições ambientais}

Os cafés especiais podem ser diferenciados por diversas formas, incluindo as condições ambientais em que são produzidos e a composição sensorial da bebida. Objetivou-se avaliar neste trabalho o efeito dos fatores altitude, face de exposição solar e cor do fruto nos atributos sensoriais dos cafés da região das Matas de Minas. Nas lavouras, pontos amostrais foram georreferenciados em quatro extratos de altitude ( $<700 \mathrm{~m} ; 700 \leq \mathrm{x} \geq 825 \mathrm{~m}, 825<\mathrm{x}<950 \mathrm{me} \geq 950 \mathrm{~m})$; duas cores de fruto da variedade Catuaí (amarelo e vermelho); e duas faces de exposição solar (Noroeste e Sudeste ). Foram utilizados cafés no estádio "cereja", que foram beneficiados e submetidos à análise sensorial. Foram avaliados os atributos sensoriais percepção geral, bebida limpa, balanço, retrogosto, doçura, acidez, corpo e sabor, compondo assim o escore final. As notas foram submetidas à ANOVA e as médias comparadas pelo teste de Tukey $(\mathrm{p}<0,05)$. Do ponto de vista sensorial, os frutos de café de ambas as cores se mostram semelhantes, assim como os cafés localizados em ambas as faces quando esses fatores foram analisados isoladamente. Entretanto, em maiores altitudes o café Catuaí Amarelo produz cafés de melhor qualidade sensorial. Da mesma forma, os cafés da face Noroeste, em maiores altitudes produzem cafés de melhor qualidade. A altitude é o fator que mais interfere na qualidade dos cafés da região. A atuação em conjunto de todos os fatores contribui para a qualidade final da bebida produzida nas Matas de Minas.

Palavras-chave: Coffea arabica; qualidade de bebida; altitude; face de exposição; cor do fruto

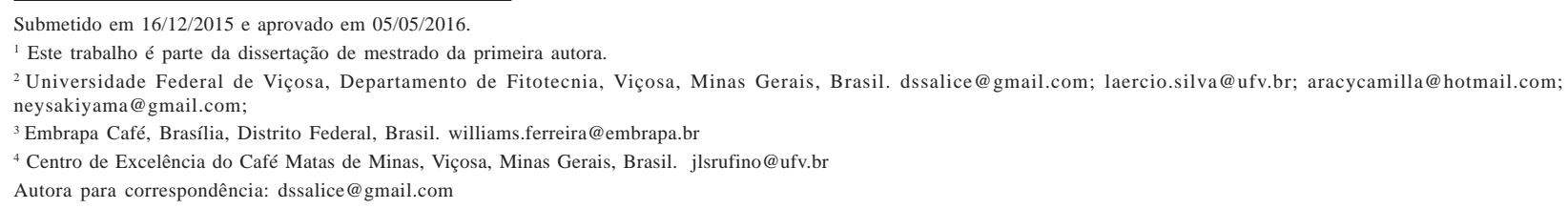




\section{INTRODUCTION}

Brazil stands out as the world's largest producer and exporter of coffee and the second largest consumer (Brazil, 2014). The state of Minas Gerais is the largest domestic producer of Arabica coffee, accounting for over $50 \%$ of total production in the country (Companhia Nacional do Abastecimento - Conab, 2014). Among the four producing regions of the state, the region Matas de Minas, comprising an extension of continuous land in the regions Zona da Mata and Vale do Rio Doce, have stood out in recent years with increasing participation in the production of specialty coffees.

Specialty coffees can be differentiated by their sensory attributes, allowing the consumer to taste and appreciate a different beverage with superior quality, providing pleasant sensations to the sense organs.

The specialty coffee segment represents approximately $12 \%$ of the international coffee market. The value of the current sales for some different coffees have a price premium ranging between $30 \%$ and $40 \%$ more compared to conventional coffee. In some cases it can reach above 100\% (Brazil Specialty Coffee Association- BSCA, 2015).

The commercial evaluation of the quality of Brazilian coffee is carried out mainly through the physical aspect and the sensory analysis, also known as "cup test", that is, depending on the type and beverage (BSCA, 2015). Regarding the analysis of specialty coffee, this evaluation becomes more rigorous because these coffees have superior quality to the export standard used in Brazil.

A good quality beverage depends on many aspects such as appropriate pre-harvest cultural practices, favorable physiological and environmental factors, inherent plant characteristics, as well as appropriate management of harvest and post-harvest processes, including the beverage preparation (Camargo, 2007). Various factors affect coffee quality, and environmental factors such as altitude and sun exposure are among the most important ones (Guyot et al., 1996; Decazy et al., 2003; Avelino et al., 2005; Alves, 2005; Bernardes et al., 2012).

According to Valeriano (2003), the direction of sun exposure plays an important role in crop evapotranspiration and water balance. In addition, the slope exposure influences air temperature, affecting the length of the production cycle and determining the harvest time, which is important for the quality of coffee beans (Ferreira et al., 2012).

Altitude also has a strong influence on air temperature changes (Cargnelutti Filho et al., 2006), which decrease with altitude (Ayoade, 2004). Lower temperatures delay fruit ripening, leading to the occurrence of more chemical changes in beans and greater accumulation of sugars, some acids and amino acids, which improves the favorable characteristics for a good beverage (Matiello et al., 2005; Vaast et al., 2006).

Studying the relation of higher altitudes and shade, Guyot et al. (1996) and Buenaventura \& Castaño (2002) found that in these conditions there is a delayed maturation of coffee fruits, resulting in increased acidity and sugar content. Other studies also reported the existence of a relationship between altitude and quality of coffee beverage, such as those performed by Guyot et al. (1996), Serrano \& Castrillón (2002), Decazy et al. (2003), Silva et al. (2004), Avelino et al. (2005) and Dal Molin et al. (2008).

It is believed that the fruit color can be related to the sensory quality of coffee; however, there are few studies that show this association. Studies under different environmental conditions (altitude and slope exposure) have found better sensory quality in yellow fruits (Taveira et al, 2011; Ribeiro, 2013).

The market of specialty coffees is growing in Brazil, providing farmers with higher prices and consumer with a more refined beverage; it is then relevant to perform the sensory analysis, relating quality of coffee with environmental factors and fruit color. Thus, the aim of this study was to evaluate the influence of the altitude, slope exposure and fruit color on the sensory attributes of coffee produced in the region of Matas de Minas.

\section{MATERIAL AND METHODS}

The region of Matas de Minas comprises 63 municipalities in which the coffee is the most important activity for the regional economy. It is located east of the state of Minas Gerais in a mountainous area of the Atlantic Forest, in the coordinates $40^{\circ} 50^{\prime}$ to $43^{\circ} 36^{\prime}$ South and $18^{\circ}$ $35^{\prime}$ to $21^{\circ} 26^{\prime}$ West. The study was conducted in 14 municipalities of the region of Matas de Minas (Figure 1).

A total of 299 sampling points were marked among the municipalities according to the altitude, slope exposure and fruit color available in each one, as well as the consent of the farmers. To facilitate the collection of coffee samples, the points were georeferenced (GPS Garmin Etrex 30) by recording latitude, longitude and altitude.

To survey the sampling points, three parameters that influence the quality of coffee were considered, namely: two fruit colors of the predominant variety in the region Red Catuaí and Yellow Catuaí (cultivars were not distinguished); four altitude ranges relative to sea level less than $700 \mathrm{~m}(<700 \mathrm{~m})$; equal to or greater than $700 \mathrm{~m}$ and less than or equal to $825 \mathrm{~m}(700 \leq \mathrm{x} \geq 825 \mathrm{~m})$; greater than $825 \mathrm{~m}$ and less than $950 \mathrm{~m}(825<\mathrm{x}<950 \mathrm{~m})$; and greater than or equal to $950 \mathrm{~m}(\geq 950 \mathrm{~m})$; and two slope exposures - North-facing (warmer) and South-facing (cooler). The South-facing slopes (Southwest and 
Southeast quadrants) get less sun during the day and the year. The North-facing slopes (Northeast and Northwest quadrants) get more sun during the day and the year. (Ferreira et al., 2012). This study considered the North slope warmer and the South slope cooler.

For each fruit color, coffee samples were collected from the four altitude ranges and from each slope exposure and analyzed, composing a 2 × 4 × 2 factorial.

Within each environment, three kilograms of cherry coffee were collected at random in approximately thirty trees per hectare. Fruits were harvested from four branches, a pair on each side of the plant, facing the space between rows. Only one sample was collected from each plot and the maximum of six coffee samples within the same farm.

Since coffee maturation at higher altitudes is slower (Ayoade, 2004; Vaast et al., 2006), the collection of fruit to obtain homogeneous samples and at the same maturation stage was as follows: the first 15 days all samples located up to $700 \mathrm{~m}$ were collected, in sequence, every 15 days, samples of altitudes between 700 and $825 \mathrm{~m}$, then between 825 to $950 \mathrm{~m}$ and, lastly, those of altitude above $950 \mathrm{~m}$.

The samples of cherry coffee were pulped in a hand pulper in continuous water flow and dried in a mechanical dryer, which was designed exclusively for this purpose by the Department of Agricultural Engineering of the Federal
University of Viçosa. The dryer consisted of galvanized sheets coated with epoxy paint, 48 trays with perforated aluminum sheet bottom and a centrifugal fan with air volume of $30 \mathrm{~m}^{3}$ air per minute. Each tray dryer contained $1.5 \mathrm{~kg}$ of parchment coffee.

The temperature of the drying air was between 35 and $40{ }^{\circ} \mathrm{C}$ until the coffee samples reached 11 to $12 \%$ moisture. The monitoring of bean moisture was carried out with a digital Gehaka G800 grain moisture tester. Temperature control was controlled by an external digital thermometer and the air heating system was control by butane. Coffee of each tray was stirred up daily to ensure uniform drying.

After drying, the coffee samples remained with endocarp (parchment), were packed in woven poly-bags, and stored in B.O.D. chamber with $60 \%$ relative humidity at $20{ }^{\circ} \mathrm{C}$ for 60 to 80 days until complete processing. Processing of coffees was carried out in the municipality of Manhumirim- MG.

Coffee samples were hulled using a DRC-1 830 portable huller, packed in plastic bags and stored until physical classification (screen and type) and sensory analysis.

Sensory analysis was performed by three tasters working at the Q-grader group, in the city of Alfenas - MG. Each coffee sample consisted of five cups and one determination per sample was performed by taster.

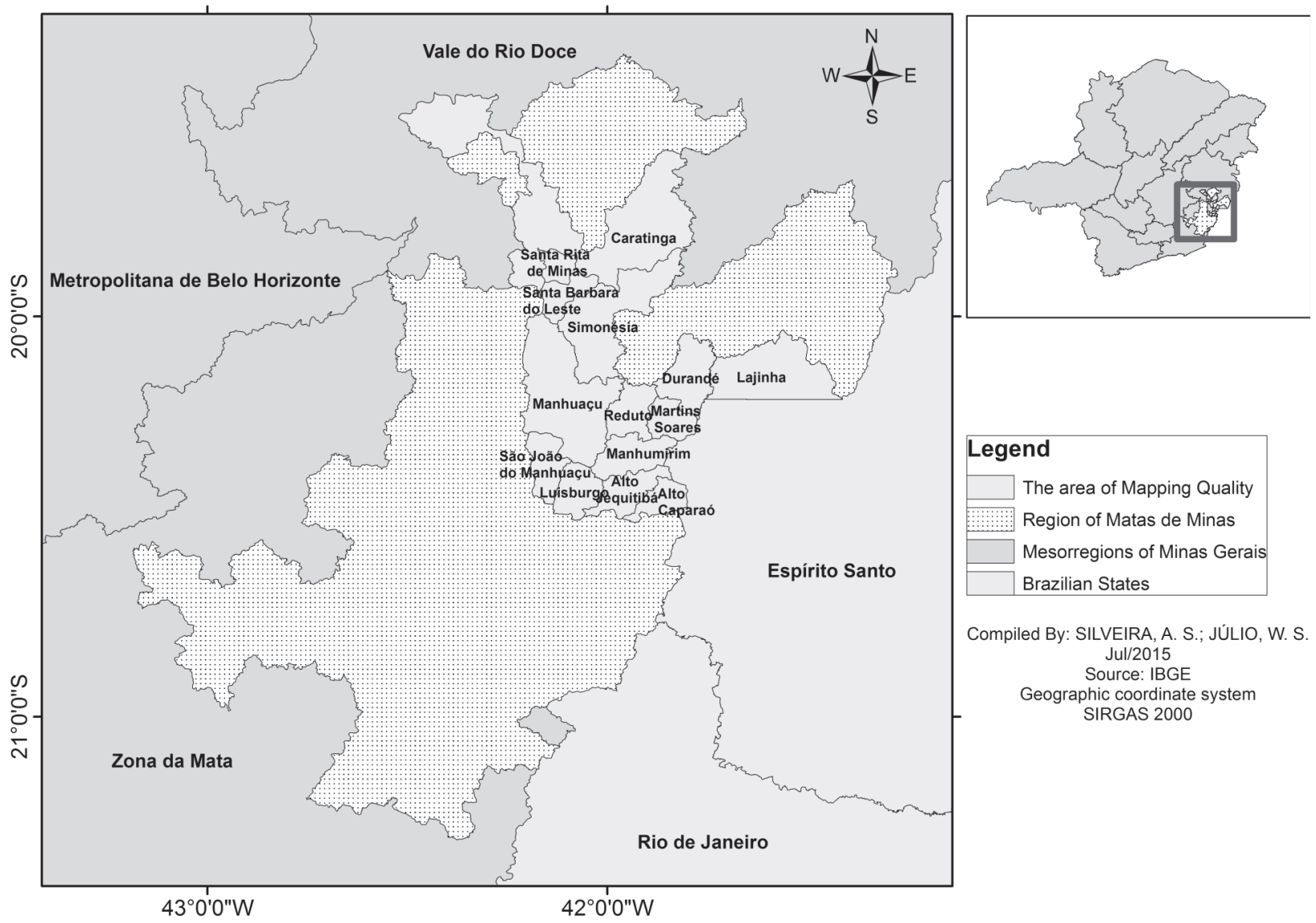

Figure 1: The region of Matas de Minas and municipalities that participated in the research.

Rev. Ceres, Viçosa, v. 63, n.4, p. 436-443, jul/ago, 2016 
Eight characteristics related to organoleptic standards of the beverage were evaluated according to the methodology of the Brazil Specialty Coffee Association (BSCA, 2015): overall perception, clean cup, balance, aftertaste, sweetness, acidity, body and flavor. All procedures for the preparation of the coffee beverage and sensory analysis followed the national and international rules of the Cup of Excellence ( $\mathrm{CoE}$ ) methodology adapted by BSCA, as well as the coffee sensory evaluation form.

In this methodology, the beverage, but not the defects, is evaluated, and the samples start with score 36 . From this point, it sums up the scores of each attribute, from 0 to 8 , to make up the final score. Beverage evaluation follows a grading scale from 36 to 100 , in which 100 points is the maximum score that a coffee can get. If the coffee sample reaches a final score greater or equal to 80 points $(80 \%)$, it is classified as specialty coffee, according to BSCA.

The results were submitted to the analysis of variance (ANOVA) at $5 \%$ level of probability $(\mathrm{p}=0.05)$. The significant differences detected by the F test were tested by the Tukey $(\mathrm{p}<0.05)$ test of mean comparison. The Shapiro-Wilk's test $(\mathrm{p}=0.05)$ was used to test the normality of data.

The statistical analyses were carried out only with the samples having the final score (average scores of the three tasters) above 80 points (236 samples), since these are considered as specialty coffees by BSCA. Scores of the three panelists were analyzed in each sample, which are designated as repetitions. Statistical analyses were performed with the statistical software SAS (Statistical Analysis System, 2014).

\section{RESULTS AND DISCUSSION}

Table 1 shows the results obtained in the analysis of variance (ANOVA) $(\mathrm{p}<0.05)$ for the eight sensory attributes and the final score.

For sweetness, the altitude ranges $<700 \mathrm{~m}$ and $\geq 950 \mathrm{~m}$ did not differ significantly from each other. But the lowest altitude range was significantly higher than the intermediate altitude rangers. Flavor was only significantly different in the altitude range $<950 \mathrm{~m}$, with better scores than altitude range $825<\mathrm{x}<950 \mathrm{~m}$ (Table 2 ).

Corroborating our results, Gair (2012), studying the effect of altitudes between 500 and $998 \mathrm{~m}$ on the quality of coffee beverage from Paraná, concluded that different altitudes did not influence the sweetness, and at altitudes above $900 \mathrm{~m}$, the coffees had superior flavor.

In areas of higher altitude coffee trees take longer to complete its cycle (Matiello et al., 2005). Thus, the bean filling period is longer, ensuring greater starch accumulation in coffee fruits. Besides, the period for the production of carbohydrates becomes sufficient to accumulate

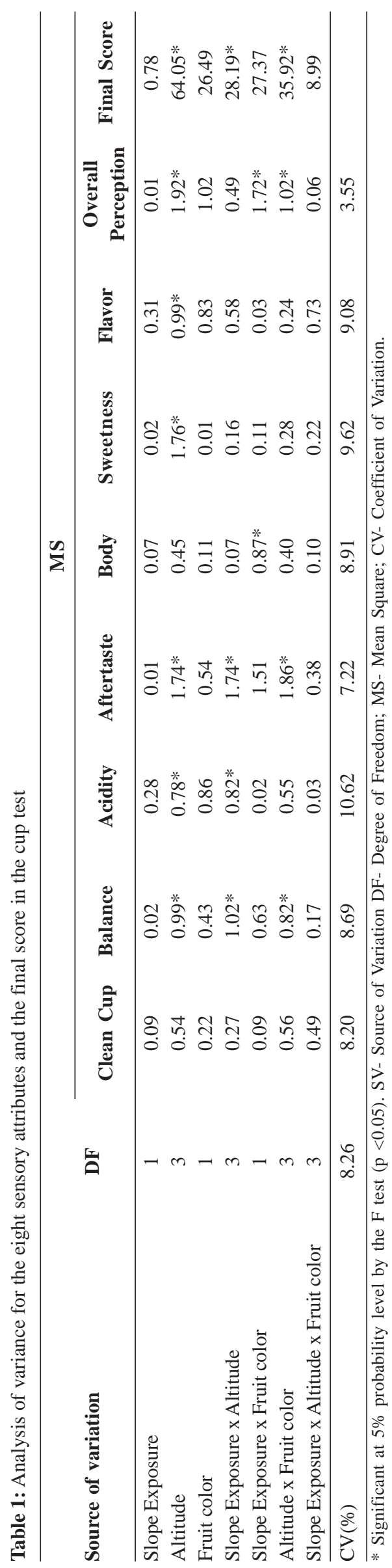

Rev. Ceres, Viçosa, v. 63, n.4, p. 436-443, jul/ago, 2016 
substances such as sugars, some acids and amino acids, which contributes to a more pleasant flavor (Vaast et al, 2006;. Laviola et al, 2007).

There was no isolated effect of slope exposure on coffee quality. However, when analyzing the interaction between slope exposure and altitude, it appears that the coffees grown on the North slope and in the altitude range $\geq 950 \mathrm{~m}$ had the scores of balance, acidity and aftertaste and the final score higher than coffees grown on the South slope (Table 3).

This behavior indicates that at higher altitudes, the coffees that have greater exposure to sunlight throughout the day and year tend to have better sensory quality. These results agree with those found by Pinto et al. (2006).

In a study on the effect of slope exposure on scores of beverage quality of coffee plantations in the municipality of Araponga, Minas Gerais state, Brazil, with 904 m average altitude, they found that the quality of beverage was significantly higher in coffees grown on the West-facing slopes than those grown on the East-facing slopes. On the other hand, Avelino et al. (2005) evaluated the quality of coffee beverage of Costa Rica at altitudes between 1,000 and 1,800 $\mathrm{m}$ and found that the crops grown in the areas facing East produced coffees with superior quality.

According to Bernardes et al. (2012), analyses of slope exposure must be compared jointly with other factors. Thus, it becomes important to study the effect of slope exposure in different climates and microclimates, showing that the results cannot be generalized to all coffee producing regions worldwide.

The unfolding of the interaction between slope exposure and fruit color showed no significant differences between the slopes for both fruit colors, for the sensory attributes body and overall perception. When comparing the effect within slopes, in the South slope, Yellow Catuaí was superior to Red Catuaí for the same attributes body and overall perception. No significant differences were observed regarding fruit color in the North slope (Table 4).

The unfolding of the interaction between altitude and fruit color showed that at the highest altitude range $(\geq 950$ $\mathrm{m})$, the Yellow Catuaí reached the highest scores in three

Table 2: Effect of altitude on the scores of the sensory attributes sweetness and flavor

\begin{tabular}{lcc}
\hline \multirow{2}{*}{ Altitudes } & \multicolumn{2}{c}{ Mean } \\
\cline { 2 - 3 } & Sweetness & Flavor \\
\hline$<700 \mathrm{~m}$ & $6.12 \mathrm{a}$ & $5.98 \mathrm{ab}$ \\
$700 \leq \mathrm{x} \leq 825 \mathrm{~m}$ & $5.92 \mathrm{~b}$ & $5.96 \mathrm{ab}$ \\
$825<\mathrm{x}<950 \mathrm{~m}$ & $5.89 \mathrm{~b}$ & $5.86 \mathrm{~b}$ \\
$\geq 950 \mathrm{~m}$ & $6.04 \mathrm{ab}$ & $6.03 \mathrm{a}$ \\
\hline
\end{tabular}

For each attribute, means followed by the same letter in the column are not significantly different by the Tukey test at $5 \%$ probability.

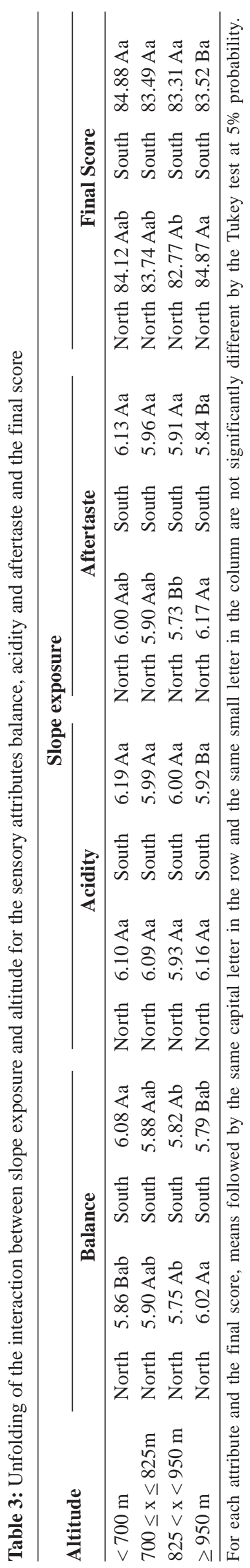


sensory attributes (balance, aftertaste, overall perception) and final score, differing significantly from the Red Catuaí.

When comparing the effect of the altitude within fruit color, no significant differences were found between altitude ranges for the Catuaí coffees. The Yellow Catuaí showed a trend to higher sensory scores at the altitude range $\geq 950 \mathrm{~m}$ (Table 5).

The results of Ribeiro (2013) agree with those obtained in the present study. In his work was to evaluate the effect of interactions between genotype, altitude, slope, and contents of some compounds present in green beans on coffee quality. For three consecutive harvests of commercial crops in Carmo de Minas, Minas Gerais state, Brazil, found significant effect for the interaction between genotype (Yellow Bourbon and Acaiá Red) and altitude (below 1,000 m; between 1,000 and 1,200 m; and above $1,200 \mathrm{~m}$ ) in relation to the total coffee score. Coffee derived from yellow fruits were significantly superior at altitudes above $1,000 \mathrm{~m}$, not differing from red fruits at elevations below $1,000 \mathrm{~m}$, which indicates that the yellow fruit respond positively in quality when grown at higher altitudes.

Studying the sensory quality of demucilated cherry coffee, from the micro-region of Serra da Mantiqueira, Minas Gerais state, Brazil, harvested at different altitudes in different environments $(<1,000 \mathrm{~m}, 1,000-1,200 \mathrm{~m}$ and $>1,200$ $\mathrm{m})$, slope exposure (North and South) and fruit color (yellow and red) of different varieties grown in the region, Taveira et al. (2011) found that coffees derived from yellow fruit, regardless of altitude and slope exposure, achieved higher sensory scores than those derived from red fruit. The authors argued that the result were due to several factors, mainly the response of crops to the production environment that cultivars are adapted.

Of the eight sensory attributes analyzed, six (balance, acidity, aftertaste, flavor, sweetness and overall perception) showed that the altitude ranges $<700 \mathrm{~m}$ and $\geq 950 \mathrm{~m}$ are significantly similar. However, work carried out by other authors (Taveira et al., 2011; Ribeiro, 2013) reported that there is a positive relationship between higher altitudes and superior quality of coffee beverage, contrary to the results observed here.

Avelino et al. (2005) assessed the cup quality of specialty coffees from two altitude terroirs of Costa Rica, Orosi (between 1,020 and 1,250 $\mathrm{m}$ above sea level; high humidity and undefined dry season) and Santa María de Dota (between 1,550 and 1,780 m above sea level; low rainfall and well-defined dry season), and found that both regions produced higher quality beverage, especially the coffees from the highest altitudes within the range studied.

Similarly, Serrano \& Castrillón (2002) studied the relationship between altitude $(1,450-1,650 \mathrm{~m})$ and quality of coffees in the municipality of Fresno, Colombia, where the annual average temperature is $20^{\circ} \mathrm{C}$, and concluded that at higher altitudes the coffee beverage was significantly better.

However, assessing the beverage of coffee quality contests of Paraná state, Brazil, and relating them to different altitudes (200-1,000 m), temperatures $\left(\leq 21^{\circ} \mathrm{C}\right.$ or $>21^{\circ} \mathrm{C}$ ) and soil textures (clayey and sandy), Voigt-Gair (2011) found that in the conditions of the study, the production of good quality coffee beverage at lower altitudes is possible. These observations reinforce that factors other than the altitude are important for the production of good quality coffee.

In a previous study in the South of Minas Gerais state, Brazil with pulped, non-defective coffees produced in two ranges of altitudes, 720 to $920 \mathrm{~m}$ and 920 to $1,120 \mathrm{~m}$, Silva $e t$ al. (2004) reported that the coffees produced in the higher altitudes had low acidity, lower body and higher sweetness, and produced better quality coffees compared with those from the lower altitude range.

In this study, the altitude range $825<x<950 \mathrm{~m}$ had the lowest average grades for five sensory attributes (balance, aftertaste, sweetness, flavor and overall perception), and, therefore, in the interactions, it was significantly different and inferior than the altitude ranges $<700 \mathrm{~m}, 700$ $\leq \mathrm{x} \geq 825 \mathrm{~m}$ and $\geq 950 \mathrm{~m}$. These results suggest that in the studied region, it is possible to obtain quality coffee at different altitudes, either below $700 \mathrm{~m}$ or above $950 \mathrm{~m}$.

Dal Molin et al. (2008), evaluating the sensory quality of specialty coffee in the Jesuítas region in the state of Paraná, Brazil, with annual average temperature of $20^{\circ} \mathrm{C}$, concluded that even at low altitudes (407-539 m), it was possible to produce full-bodied coffee with low percentage of defects and beverage quality equivalent to strictly soft (slightly sweet, smooth and slightly astringent flavor) and hard (rough, astringent and without strange flavors), i.e., high quality beverage.

Table 4: Unfolding of the interaction between slope exposure and fruit color for the sensory attributes body and overall perception

\begin{tabular}{|c|c|c|c|c|c|c|c|c|}
\hline \multirow{3}{*}{$\begin{array}{l}\text { Fruit color } \\
\text { Yellow }\end{array}$} & \multicolumn{8}{|c|}{ Slope exposure } \\
\hline & \multicolumn{4}{|c|}{ Body } & \multicolumn{4}{|c|}{ Overall Perception } \\
\hline & North & $6.07 \mathrm{Aa}$ & South & $6.17 \mathrm{Aa}$ & North & $5.99 \mathrm{Aa}$ & South & $6.11 \mathrm{Aa}$ \\
\hline Red & North & $6.12 \mathrm{Aa}$ & South & $6.07 \mathrm{Ab}$ & North & $6.02 \mathrm{Aa}$ & South & $5.92 \mathrm{Ab}$ \\
\hline
\end{tabular}

For each attribute, means followed by the same capital letter in the row and the same small letter in the column are not significantly different by the Tukey test at $5 \%$ probability. 
According to Alves et al. (2011), coffee is essentially a product of "terroir", i.e., directly influenced by environmental aspects of both natural and human origin. Knowing and explaining what affects coffee quality becomes an extremely complex task, especially when dealing with a country like Brazil, which has a large extension of the crop in its territory, with different soil and climatic conditions.

Thus, it is necessary to develop new research since there are still few studies relating the influence of edaphoclimatic factors with the sensory quality of coffees, and many results already found need to be proven by further studies.

\section{CONCLUSIONS}

The factors altitude, slope exposure and fruit color influence the sensory quality of coffee when analyzed separately (Altitude), or their interactions (Altitude x Slope Exposure; Altitude x Fruit Color and Slope Exposure x Fruit Color).

From the sensory point of view, the coffees Yellow Catuaí and Red Catuaí are similar, as well as the coffees grown in the North-facing and South-facing slopes, when these factors are analyzed separately. However, at higher altitudes Yellow Catuaí produces coffees with better sensory quality. Similarly, the coffees of North-facing slope, at higher altitudes, produce better quality coffee.

Altitude is the main factor that influences the sensory quality of coffee in the region of Matas de Minas, Minas Gerais state, Brazil.

\section{ACKNOWLEGMENTS}

The authors thank the National Council for Scientific and Technological Development (CNPq) for granting the Master's scholarship to the first author.

\section{REFERENCES}

Alves EA (2005) Análise da variabilidade espacial da qualidade do café cereja produzido em região de montanha. Dissertação de Mestrado. Universidade Federal de Viçosa, Viçosa. 64p.

Alves HMR, Volpato MML, Vieira TGC, Borém FM \& Barbosa JN (2011) Características ambientais e qualidade da bebida dos cafés do estado de Minas Gerais. Informe Agropecuário, 32:0112.

Avelino J, Barboza B, Araya JC, Fonseca C, Davrieux F, Guyot B \& Cilas C (2005) Effects of slope exposure, altitude and yield on coffee quality in two altitude terroirs of Costa Rica, Orosi and Santa Maria de Dota. Journal of the Science of Food and Agriculture, 85:1869-1876.

Ayoade JO (2004) Introdução à climatologia para os trópicos. $10^{\mathrm{a}}$ ed. Rio de Janeiro, Bertrand Brasil. 332 p.

Bernardes T, Moreira MA, Adami M \& Rudorff BFT (2012) Diagnóstico físico-ambiental da cafeicultura no Estado de Minas Gerais-Brasil. Coffee Science, 7:139-151.

Rev. Ceres, Viçosa, v. 63, n.4, p. 436-443, jul/ago, 2016 
Brasil (2014) SPAE - Secretaria de Produção e Agroenergia. DCADepartamento do Café. Informe estatístico do café. Brasília, Ministério da Agricultura, Pecuária e Abastecimento. 22p.

BSCA - Brazil Specialty Coffee Association (2015) Disponível em: <http://bsca.com.br/cafes-especiais.php>. Acessado em: 30 de janeiro de 2015

Buenaventura C \& Castaño J (2002) Influencia de la altitud en la calidad de la bebida de muestras de café procedente del ecotipo 206B en Colombia. Cenicafé, 53:119-131.

Camargo MBP (2007) Influência do clima na produtividade de grãos e na qualidade da bebida do café. In: Salva TJG (Ed.) Café de qualidade: aspectos tecnológicos, científicos e comerciais. Campinas, IAC. p. 324-330.

Cargnelutti Filho A, Maluf JRT, Matzenauer R \& Stolz AP (2006) Altitude e coordenadas geográficas na estimativa da temperatura mínima média decendial do ar no Estado do Rio Grande do Sul. Pesquisa Agropecuária Brasileira, 41:893-901.

Conab - Companhia Nacional de Abastecimento (2014) Acompanhamento da Safra Brasileira de Café, Safra 2014 - Quarto Levantamento. Brasília, Companhia Nacional de Abastecimento. $51 \mathrm{p}$

Dal Molin R, Andreott M, Reis AR, Furlani Junior E, Braga GC \& Scholz MBS (2008) Caracterização física e sensorial do café produzido nas condições topoclimáticas de Jesuitas, Paraná. Acta Scientiarum Agronomy, 30:353-358.

Decazy F, Avelino J, Guyo B, Perriot JJ, Pineda C \& Cilas C (2003) Quality of different honduran coffes in relation to several environments. Journal of Food Science, 68:2356-2361.

Ferreira WPM, Ribeiro MF, Fernandes Filho EI, Souza CF \& Castro CCR de (2012) As características térmicas das faces noruega e soalheira como fatores determinantes do clima para a cafeicultura de montanha. Brasília, Embrapa Café. 34 p. (Documentos, 10).

Gair R (2012) Efeito da altitude na qualidade da bebida do café Dissertação de Mestrado. Universidade Estadual de Londrina, Londrina. $57 \mathrm{p}$.

Guyot B, Gueule D, Manez JC, Perriot J, Giron J \& Villain L (1996) Influence de l'altitude et de l'ombrage sur la qualité des cafes arabica. Recherche Dèveloppement, 3:272-283.
Laviola BG, Martinez HEP, Salomão LC, Cruz CD, Mendonça SM \& Neto AP (2007) Alocação de fotoassimilados em folhas e frutos de cafeeiro cultivados em duas altitudes. Pesquisa Agropecuária Brasileira, 42:1521-1530.

Matiello JB, Santinato R, Garcia AWR, Almeida SR \& Fernandes DR (2005) Cultura de café no Brasil: novo manual de recomendações. Rio de Janeiro, MAPA/PROCAFÉ. 438p.

Pinto FAC, Alves EA, Queiroz DM, Santos NT \& Abrahão AS (2006) Orientação da face de exposição ao sol de parcelas de cafeeiros produzidos em região de montanha e seu efeito na qualidade de bebida. Revista Brasileira de Armazenamento, 9:3239.

Ribeiro FC (2013) Métodos alternativos para armazenamento de cafés especiais. Tese de Doutorado. Universidade Federal de Lavras, Lavras. 107p.

SAS Institute INC (2014) System Requirements for SAS® 9.4. Foundation for Microsoft Windows for x64. Cary, SAS Institute Inc.

Serrano CEB \& Castrillón JJC (2002) Influência de la altitud en la calidad de la bebida de muestras de café procedente del ecotopo 206 B en Colombia. Cenicafé, 53:119-131.

Silva RF, Pereira RGFA, Borém FM \& Muniz JA (2004) Qualidade do café-cereja descascado produzido na região sul de Minas Gerais. Revista Ciência Agrotecnologia, 28: 1367-1375.

Taveira JH, Borém FM, Rosa SDVF, Ribeiro DE, Chaves ARCS, Ferreira DA, Ferreira IT \& Ribeiro RC (2011) Aspectos fisiológicos de grãos de café produzidos em ambientes variados da micro região da Serra da Mantiqueira. In: $7^{\circ}$ Simpósio de Pesquisa dos Cafés do Brasil, Araxá. Anais, Epamig. 4p.

Vaast P, Bertrand B, Perriot J, Guyot B \& Génard M (2006) Fruit thinning and shade improve bean characteristics and beverage quality of coffee (Coffea arabica L.) under optimal conditions. Journal of the Science of Food and Agriculture, 86:197-204.

Valeriano MM (2003) Curvatura vertical de vertentes em microbacias pela análise de modelos digitais de elevação. Revista Brasileira de Engenharia Agrícola e Ambiental, 7:539-546.

Voigt-Gair L (2011) Fatores edafoclimáticos e atributos sensoriais de cafés dos concursos "Café Qualidade Paraná" (2004 a 2009). Dissertação de Mestrado. Universidade Estadual de Londrina, Londrina. 54p. 